\title{
Analyzing the Effect of the Senior Management's Support on the Relationship between Factors Affecting and Employees' Performance in the Al-Zawiya University of Libya
}

\author{
Nasreddin Ramadhan Dukhan ${ }^{1}$, Norhisham Mohamad ${ }^{1} \&$ Asbi B Ali ${ }^{1}$ \\ ${ }^{1}$ Management and Science University in Malaysia (MSU), Malaysia \\ Correspondence: Nasreddin Ramadhan Dukhan, Management and Science University in Malaysia (MSU), \\ Malaysia. E-mail: Nasserdukhan@yahoo.com
}

Received: December 19, 2016

doi:10.5539/ass.v13n3p42
Accepted: January 19, 2017 Online Published: February 15, 2017

URL: http://dx.doi.org/10.5539/ass.v13n3p42

\begin{abstract}
This study aims to test the influence of the senior management's support as a moderating variable on the relationship between the independent factors (Training, Empowerment, Motivation and Communication) and the dependent variable (Performance of Employees). (SEM-AMOS) is used to test the impact of the moderating variable. Where it is depended on the method of sampling or analysis of what is known as multiple-groups analysis. The paragraphs of the senior management's support variable are collected and divided into two groups according to the mean of the total paragraphs. In addition, according to the relative weights given to the paragraphs of the questionnaire, using a five- point's Likert scale: $1=$ strongly disagree to $5=$ strongly agree. The first group consisted of the grades less than the mean and it is considered as the group which is non-supporters of the existence of support. While the second group consisted of the grades higher than the mean and considered as the group which is a supporter of the existence of support. The study found that the model of study in the presence of the support of the senior management's is appropriate for the second group and inappropriate in light of the lack of support by the senior management's support for the first group.
\end{abstract}

Keywords: Training, Empowerment, Motivation, Communication, Performance of Employees, Senior Management's Support

\section{Introduction}

Mudor and Tookon (2011) pointed out that every organization seeks success especially due to today's competitive environment. Regardless of their size and market, organizations strive to maintain the best employees and acknowledge their important role and influence on the efficiency of such organizations. However, it is important for organizations to establish a strong and positive relationship with the employees and guide then in fulfilling their work tasks and achieving job satisfaction (Fisher, 2012). In achieving such goals and objectives, organizations employ various strategies for competing in highly competitive markets and increasing their performance. Nevertheless, only a few organizations take into consideration human capital as the main asset that can either achieve or fail to achieve such desired success of originations. If not managed properly, humans can cause failure of the organization and high staff turnover (Fisher, 2012). As emphasized by Ran (2009), it is necessary for employers to motivate and enable their employees to achieve a high level of job satisfaction. Yet, development of such job satisfaction and motivation-oriented programs and policies is a time and money-consuming task. It is easy to justify policies related to employees as long as there is understanding of the value of work-related motivation among employers. However, organizations may not be able to achieve their goals and the desired success if there is a lack of job satisfaction and motivation among employees.

There are diverse needs for people which are constantly competing with each other. Such needs are also variable with an individual. Each individual has a different mixture and strength of needs, and while some people may strive for achievement, others may focus on security. It is argued that managers'/ supervisors' understanding, prediction, and control of employees' behavior will enable them to have better knowledge of what their employees want from their jobs. Therefore, managers'/ supervisors' understanding of what and how to motivate their employees rather than assuming this becomes a matter of importance (Gurland \& Lam, 2008). It is also indicated that top management plays an important role in fulfilling synergy between the activities and operations 
of the organization. This is because of the importance of top management as a source for achieving organizational goals. It is also responsible for the understanding of the organizational principles and values of its employees. It generates synergy and compatibility between them (Manna, 2012; Turban, 2010, p. 236). With the speedy technological advances and information technology today, the structure of organizations appears to have a crucial role in the success of the various organizations (Chen, 2007). However, this demands to develop and establishing an effective organizational structure which is capable of providing the necessary conditions for achieving the organizational goals and success, satisfying employees' needs, empowering them or making them autonomous and motivating them to be initiative and creative (Ifinedo, 2007). Such empowerment of employees is expected to make them active participants and contributors to the goals and success of organizations since it coordinates and integrates employees at the individual and group levels. It also assists in achieving synergy and consistency and creates the conditions that are necessary for active participation self-fulfillment and accomplishment. This also enables employees to feel a strong sense of belonging to and feel committed to their organizations (Wiengarten et al., 2013). The support of top management to employees is regarded as an important and critical issue to achieve and maintain a competitive advantage. The role of top management is constantly recognized in identification and exploitation of opportunities and in the process of making decisions that affect innovation, thus adding value to the businesses (Elenkov et al., 2005; Ireland \& Hitt, 1999; Finkelstein \& Hambrick, 1996). Previous researchers have paid considerable attention to the top management-innovation interaction (West et al., 2003; Kim et al., 2012; Sharma \& Rai, 2003). Results of many previous related studies are indicative of the positive impact of top management on innovation. Moreover, such studies reported that innovation is positively related or correlated with organizational performance (Bowen \& Steel 2010; Ryan \& Tipu, 2013). Yet, in the context of developing countries, top management is still challenged by the dynamics of working conditions, and innovation is still needed as a means that can contribute to achieving a sustainable competitive advantage for survival in the market (Perry-Smith, 2006; Puranam et al., 2006). Therefore, the aim of the present study was to examine the role of the support of Senior Management in reinforcing the relationship among these variables: Training, Empowerment, Motivation, Communication, and Performance of Employees.

\section{Issue}

Although Top management plays an important role in enhancing the performance of employees, and making decisions that enhance the creation and execution of knowledge successfully (Van de Ven, 1993; Storey, 2000; Aragón-Correa et al., 2007) and organizations, many organizations in developing countries such as Libya do not pay much attention to human resource management in order to ensure such effective performance of their employees. There is little-related research on human resource management in Arab countries in general and Libya particular in comparison to the wide number of researches in Europe, America, and different parts of Asian continents (Esmael, 2016). Moreover, these few studies in the Libyan context focused their investigation on factors affecting the Employees' Performance at work place such as Training, Empowerment, Motivation, communication while ignoring the importance of as far as the authors of this study are aware, there are no empirical studies examining the Libya investigating the moderating effect of senior management, which is the subject of this study. In order to bridge the above-mentioned gap in previous research.

\section{The Objective of the Study}

There are two purposes of this research. First, is aim to provide a better understanding of the factors that will affect the employee performance in the Al-Zawiya University of Libya. Secondly is to investigate the moderating effect of the senior management between Training, Empowerment, Motivation, communication and employees' performance.

\section{Significance of the Study}

The purpose of this study is to investigate on factors that affecting employee performance in the Al-Zawiya University of Libya and especially in the presence of support from senior management. in These days, University administration should concern about the factors that affecting employee performance due to it will affect the entire organization as well, a successful organization is regarding on how an employee perform their job, and what factor will affect an employee performance in the organization.

\section{Theoretical Background and Hypotheses}

\subsection{Employees' Performance}

As defined by Brown (2008), performance refers to how a given individual performs certain tasks and how he/she views such task completion. In addition, Hersen (2004) defined it from a different perspective that takes into account quantifying employee's work-related output or outcomes, including a number of sales, numbers sold 
as well his/her behavioral dimension, such as work-oriented communication, making decisions and skills for solving problems. According to Baldwin (2008), job performance is defined as a process of making actions in an efficient and effective manner in order to achieve the goals of the job. This means that employees, in performing their work, employ their abilities, skills, capabilities, previous experience and knowledge to carry out the task demanded or requested by their subordinate in effectively and efficiently (Kirkpatrick, 2006).

\subsection{Training and Development}

In the field of human resource management, training is recognized as an important domain that focuses on how to foster the organizational activity through empowering employees at the individual and group levels in a given organization to achieve better performance. Previous research highlighted several labels used for training, including employee development, human resource development, and learning and development (Harrison, 2005). In terms of defining it, training is a process that aims at changing individuals' knowledge, skills, attitudes, and/or behavior (De Cenzo \& Robbins, 1998). This definition underlies the role of training in designing and supporting learning activities which lead to achieving the desired level of performance. On the other hand, development is a concept which typically portrays the growth at the long run, constant learning and directing attention more on the potential needs of individuals in the future. Thus, whereas the focus of training is the duties or responsibilities of a given job, the focus of development is on the future job responsibilities. Although the two concepts are distinguished from each other, sometimes they are used interchangeably, and even they are given one label as performance consulting that places an emphasis on either the outcome of training and development or on the way humans perform a given task as a result of their learning (Robinson, 1995). In brief, training can be defined as an educational process that aims at empowering humans with new information, enabling them to re-learn and reinforce existing knowledge and skills, and most importantly, making them able to think of new ideas and alternatives as to enhance their work performance. Efficient training provides employees with current, related and valuable information that assists them on what and how to develop their skills and behaviors which, in turns, will benefit their workplace (Montana \& Charnov, 2000).

Creating a positive long-term impact on employees is the main aim of training. In other words, training aims to create certain actions and promote trainees' sense of commitment through the integration of what they have learnt in the training into their work. Thus, training can be provided for the purpose of developing skills of individuals and groups. Generally, the process of training encompasses what and how to present and learn, especially content as a way to enable trainees to enhance their skills and behaviors pertinent to their work (Karlan \& Valdivia, 2011). It reflects what informal efforts constantly made by organizations to enhance employees' performance and self-fulfillment using various educational methods and programmes. In the modern workplace, such training is introduced in the form of many practical applications that vary from instruction in highly specific job skills to long-term professional development. Recently, training and development have emerged as a function of formal business, an integral element of strategy, and a recognized profession that is framed or grounded on distinct theories and methodologies

\subsection{Empowerment}

Originally, the term of empowerment means authorizing or giving (Tulloch, 1993). In discussing its meaning, Wallach \& Mueller, (2006) concluded that empowerment means enabling employees or providing them with the power to take decisions and rendering them responsible for the results. In addition, Besides, Boehm, A., \& Staples (2002) claimed that, with proper training, power makes transformation of control and conversion of the entire organization or firm into a model for empowerment model. Through empowerment, entrusted employees can access a certain degree of authority and become able to take decisions in accomplishing their work tasks. In other words, such employees become somehow free to employ any methods or ideas that they see efficient in completing tasks. Many previous related studies concluded that as a well-known managerial concept, empowerment of employees plays a potential role in providing several benefits, including promoting their organizational performance, strengthening their task commitment, creating among them higher levels of initiative in taking roles and responsibilities, providing them with opportunities for more innovation and learning, enabling them to be highly satisfied with their work and fostering the organization culture (Michal, 2011).

\subsection{Motivation}

In defining motivation, DeCenzo and Robbins (1996) stated that it is the individual's desire or willingness to perform a given task and the ability to meet some needs under certain conditions. Regardless of the size, today, many organizations or enterprises in different sectors are widely engaged in practicing employees' motivation. This indicates that such enterprises are highly aware of the role of motivating their employees in achieving the desired organizational goals. Thus, those motivated employees who are self-satisfied, self-fulfilled and 
committed are expected to be more capable of producing a better quality of work and they oblige to the organizations' policies, which will extensively materialize efficiencies and competitive advantages. Motivation fosters employees' engagement in their work by making them feel that what they do is more meaningful and interesting, and it increases their productivity and enhances their subsequent job performance (Kamery, 2004; Ekerman, 2006). Regarding its importance, employee motivation has been documented in previous research as one of the most important and essential factors in employee's self-achievement and ultimately, in the achievement of the organizational targets and goals (Berman et al., 2010). As asserted by Ololube (2006), work motivation, regardless of whether it is intrinsic or extrinsic, is necessary for workers as they feel that they work for a fundamental reason life. Thus, it reflects certain complicated forces and needs that empower the individual to carry out a given task (Shulze \& Steyn, 2003). As an essential component of business operations, motivation also plays an important role in achieving employees' job satisfaction, creating a sense of pride among them and making them more committed to their work, thus improving their performance and productivity (Linz et al., 2006). Similarly, for Islamic organizations, motivation is useful for investigating employees' performance, although the findings may be equivocal.

\subsection{Communication}

Communication is defined as the process of contacting and interacting with individuals or groups for the purpose of information delivery and sharing as well as meanings and understanding (Fisher, 1980). As a predicator of employees' success, communication competency has been given by mixed opinions and views from several professionals (Ryan \& Sackett, 1987). Moreover, communication is recognized an important element in the success of any organization since it enables such organizations to have an influence on how to achieve their goals as evidenced by the link between communication and work productivity (Camden \& Witt, 1983; Papa \& Tracy, 1987; Snyder \& Morris, 1984). Moreover, efficient communication enables a given company to well coordinate its teams or units, whereas lack of such communication can cause in running business operations or lead to failure of the company and its employees to achieve the goals. It has been argued that people engaging in communication should be skilled and able to convey their ideas. Otherwise, there might be a misunderstanding of what needs to be conveyed. However, this is dependent on the facilities in organizations and mangers' actions to see the acceptability of information in order to have an accurate delivery of such information. As an important key element, communication enables managers to exchange feedback with employees, which has an effect on employees' work motivation. This is relevant to the circumstances that are currently faced by the employees, including the right time of delivering such information. Hence, their performance depends on their communication with managers and the messages received by them. Improving employees' job performance requires managers' initiatives to provide their employees with opportunities to learn new skills by communicating with them.

\subsection{Senior Management's Support}

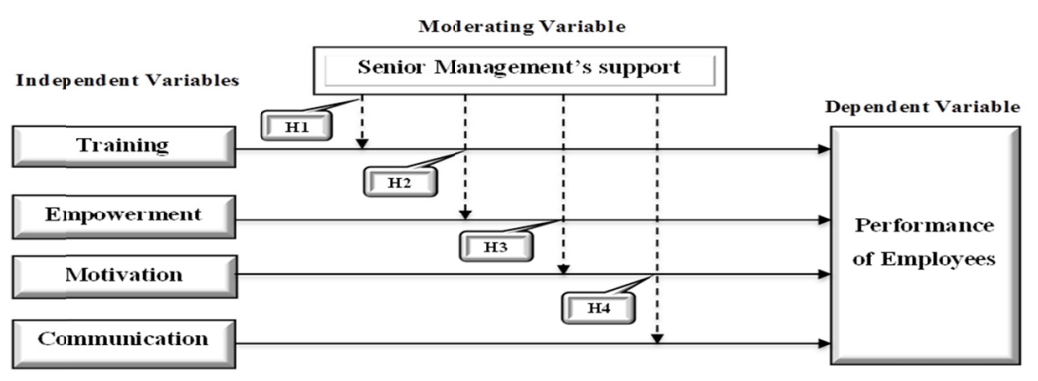

Figure 1. Conceptual model

His support of Senior Management is necessary to develop innovations through an appropriate work environment and to take appropriate decisions that facilitate successful knowledge development and implementation or application (Van de Ven, 1993; Storey, 2000; Aragón-Correa et al., 2007). Ideal top management is the one that is deeply aware of employees' needs and that provides them with an incentive as a means to motivate and encouraging them to innovate in carrying out work related tasks and solving work problems. It also assists employees to be able to address their needs for empowerment, personality improvement, achievement, and enhance self-efficacy (Jung et al., 2003; Ryan \& Tipu, 2013; Abrell et al., 2011; Taylor et al., 2009). As pointed out by many previous researchers, top management plays an important role in the outcomes of organizations (Cho \& Hambrick, 2006; Kor, 2003; Stam \& Elfring, 2008; Smith \& Tushman, 2005; Wu et al., 
2005; Oke et al., 2009; Chahine \& Goergen, 2013; Agbim et al., 2013). According to other researchers, the support of top management support is a key element in affecting adoption of innovative activities in organizations (Elenkov et al., 2005; Makri \& Scandura, 2010; Denti, 2012; Kim et al., 2012; Hoang et al., 2009; Al-Refaie et al., 2011). In this study, the following research hypotheses are relevant to senior management's support variable as displayed in Figure 1.

\section{Hypotheses}

6.1 Supportive Senior Management reinforces the relationship between Training and Employees' Performance in the Al-Zawiya University of Libya.

6.2 Supportive Senior Management reinforces the relationship between Empowerment and Employees' Performance in the Al-Zawiya University of Libya.

6.3 Supportive Senior Management reinforces the relationship between Motivation and Employees' Performance in the Al-Zawiya University of Libya.

6.4 Supportive Senior Management reinforces the relationship between Communication and Employees' Performance in the Al-Zawiya University of Libya.

\section{Data Collection and Sampling Design}

A questionnaire was used to acquire empirical data related to each of the study variables. The questionnaire was distributed to Employees in the Al-Zawiya University of Libya. Total of (500) questionnaires were distributed. (407) questionnaires were returned, of which (361) were valid, which represents $72.2 \%$ response rate. The data was collected over a period of time from (January to April 2016).

\section{Research Methodology}

\subsection{Research Design}

The present study used a quantitative research design, specifically the descriptive survey design. This is because such design accurately and objectively describes the characteristics of a situation or phenomenon being investigated in a given study. It provides a description of the variables in a particular situation and, sometimes, the relationship among these variables rather than focusing on the cause-and-effect relationships (Johnson \& Christensen, 2012:366). Thus, this study used a questionnaire which was developed from previous research in order to measure the relationships among the investigated variables. As an approach to the easy collection of data, the survey used in this study encompasses six main Variables: Training, Empowerment, Motivation, Communication, Performance of Employees, and Senior Management's Support. These Variables were adopted from the literature review of previous related research from these studies (Tavitiyaman, 1996; Ronah, 2015; Chng et al., 2014; Njambi, 2014; Yasir, 2011; Neelam et al., 2014). Thus, the entire survey used in this study comprises 24 items which had to be responded to by the respondents using a five- point's Likert scale: $1=$ strongly disagree to $5=$ strongly agree. Before distributing the survey to the participants, it was translated into Arabic because the participants cannot read in English.

\section{Statistical Analysis Used in this Study}

\subsection{Model Fit}

The fit of the measurement model was assessed using the following statistics and indices: Chi-square (2), the ratio of the Chi-square to the degrees of freedom (DF), Goodness-of-fit index (CFI), Root-mean-square residual and Root Mean Squared Error (RMSEA). Chi-square/df values less than or equals 3 indicates a good model fit, and between 2.0 and 5.0 is acceptable level (Hair et al., 2010; Schumacker and Lomax, 2004). CFI values should be greater than 0.9 (Wang \& Wang, 2012; Hair et al., 2010). RMSEA values less than 0.10 indicate good fit (Devaraj et al., 2002). The goodness of fit indices of the measurement model is presented in (table 3); according to these results we can infer that the measurement model was reasonably fitted to the data set.

\subsection{Reliability and Construct Validity}

According to Hair, Black, Babin, Anderson (2010) the employment of factor loading composite reliability (CR) and average variance extracted (AVE) to determine the convergent validity if it equals to or greater than 0.5 $(\geq 0.5)$ and the composite reliability equals to or greater than $0.6(\geq 0.6)$ if were recommended by Sekaran and Bougie, (2010). Also, (AVE) reading values should be greater than 0.5 ( $\geq 0.5)$ (Fornel \& Larker, 1981).

\section{Analyzing the Impact of the Senior Management's Support}

In this study the hypotheses moderating variable (Senior Management's support) by using (Multiple-Groups analysis by Amos) method and through structural equation modeling. Where the respondents' answers will be 
divided into two groups (the first group is not a supporter of the support, the second group is a supporter of the support) depending on the mean of the total paragraphs and according to the weights given to the paragraphs of the questionnaire. The comparison between the indicators of the Conceptual model it by using the group which is not supporter of the Senior Management's support (first group) and the indicators of the Conceptual model it by using the group which is supporter of the Senior Management's support (second group). If there are differences in the values of these indicators between the two groups, it indicates the presence of the influence of the variable of the Senior Management's support on the tracks, and relationships between factors affecting and performance of employees.

\section{Results}

\subsection{Descriptive Statistics for the Senior Management's Support as Moderating Variable}

The mean of the Senior Management's support variable was (60.2770) with a standard deviation of (12.756), and the minimum was (26) and the top end (78). Depending on the mean as a key factor and taking into consideration the distribution of the sample, the sample is divided into two groups. The first group is not supporter of the senior management's support which is from (26) to (61) and numbered 130 and by (36\%), while the second group is supporter of the senior management's support which is from (62) to (78) and numbered 231 and by $(64 \%)$, as shown in table (1). We conclude that there is a rapprochement between the two groups. The first group (low-group) consisted of the grades less than the mean and it is considered as the group which is not a supporter of the existence of support. While the second group (high-group) consisted of the grades higher than the mean and considered as the group which is a supporter of the existence of support. It is happened according to the weights given for the paragraphs of the questionnaire strongly agree (5), agree (4), neutral (3), disagree (2), Strongly Disagree (1).

Table 1. Descriptive statistics for the moderating variable (the senior management's support)

\begin{tabular}{|c|c|c|c|c|c|c|c|}
\hline No & Moderating & & Groups Level of Variable & Frequency & Percent & Mean & Std. \\
\hline \multirow{3}{*}{1} & \multirow{3}{*}{$\begin{array}{l}\text { The senior } \\
\text { Management's } \\
\text { support }\end{array}$} & First group & $\begin{array}{c}\text { not a supporter of the senior management's } \\
\text { support }\end{array}$ & 130 & $36 \%$ & \multirow[b]{2}{*}{60.27} & \multirow[b]{2}{*}{12.75} \\
\hline & & \multirow[t]{2}{*}{$\begin{array}{l}\text { Second } \\
\text { group }\end{array}$} & $\begin{array}{l}\text { a supporter of the senior management's } \\
\text { support }\end{array}$ & 231 & $64 \%$ & & \\
\hline & & & Total & 361 & 100.0 & - & - \\
\hline
\end{tabular}

\subsection{Construct Validity and Reliability of the Senior Management's Support}

The results of the goodness-of-fit of the final revised of the senior management's support model showed that normed chi- square (CMIN/DF) was (3.311) the CFI was (0.975) and RMSEA was (0.080).In addition to the lodging for the parameters factor ranged from 0.61 to 0.91 , with all parameters were above $0.5(\geq 0.5)$. The reliability was greater than $0.7(\geq 0.7)$, it ranged from 0.943 to 0.953 , the (AVE) reading was 0.62 where the value was greater than $0.5(\geq 0.5)$. Consequently, all results fulfilled the (AVE), and the reliability discriminant validity of the model. In general, the measurement model of the senior management's support model was fit and fulfilled the construct as depicted in Table (2). Figure (2) shows the adequacy of the final revised of the senior management's support.

Table 2. Construct Validity and Reliability of the senior management's support model

\begin{tabular}{ccccccccc}
\hline Items & Reliability & Estimate & S. E. & C. R. & P & Loading & SMC & AVE \\
\hline M1 & 0.949 & 0.7208 & 0.041 & 17.392 & $* * *$ & 0.72 & 0.52 & 0.62 \\
M2 & 0.947 & 0.7772 & 0.038 & 20.101 & $* * *$ & 0.78 & 0.61 & - \\
M3 & 0.948 & 0.7977 & 0.044 & 18.101 & $* * *$ & 0.74 & 0.55 & - \\
M4 & 0.945 & 0.9101 & 0.037 & 24.113 & $* * *$ & 0.86 & 0.73 & - \\
M5 & 0.943 & 1.0000 & - & - & - & 0.91 & 0.83 & - \\
M6 & 0.946 & 0.8718 & 0.036 & 24.235 & $* * *$ & 0.80 & 0.65 & - \\
M7 & 0.953 & 0.5353 & 0.040 & 13.345 & $* * *$ & 0.61 & 0.37 & - \\
M8 & 0.951 & 0.6079 & 0.036 & 16.766 & $* * *$ & 0.71 & 0.50 & - \\
M9 & 0.945 & 0.8258 & 0.036 & 22.350 & $* * *$ & 0.89 & 0.80 & - \\
M10 & 0.945 & 0.8263 & 0.033 & 24.644 & $* * *$ & 0.87 & 0.75 & - \\
M11 & 0.945 & 0.8655 & 0.034 & 24.889 & $* * *$ & 0.87 & 0.75 & - \\
\hline
\end{tabular}

S.E. Standard Error, C.R.: Critical Ratio, P: Probability, SMC: Squared Multiple Correlations. AVE: Average Variance Extracted 


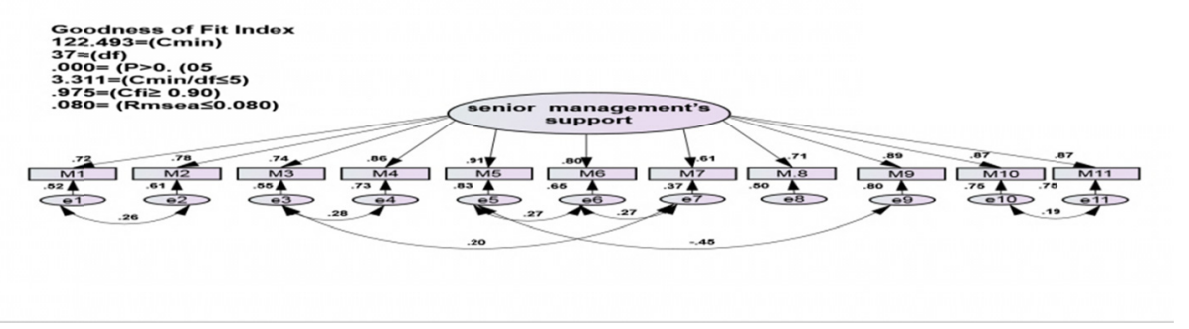

Figure 2. CFA of the senior management's support model

\subsection{Construct Validity and Reliability of the Conceptual Model without the Division of Groups}

Factor loadings mean that the correlations between the factors and the items of the questionnaire that represent these factor (e.g. the correlation between the Training and the items of this factor). The value of such relation or correlation should be at least (0.50). It is evident from the outline of the model in Figure (3) and Table (3) that the saturation of the factor loadings or correlations between the variables as embodied in the model through the rectangles and the underlying factors as manifested in circles was high and exceeded $(0.50)$. These are usually called the saturation or loadings or parameter estimates in the table which ranged from the least value (0.58) between the (Communication) and its third item (CO.3) to the highest value (0.90) between the Training and its item (TR.2) in the model. Moreover, the (CR) for each relation between the underlying factors and variables representing it was higher than (1.964) for all relations, which means that such values are significant at (0.05). Since the (CR) is higher than (1.964), the levels of such relations are statically significant. Such results confirm that there are correlations or relations between the five factors.

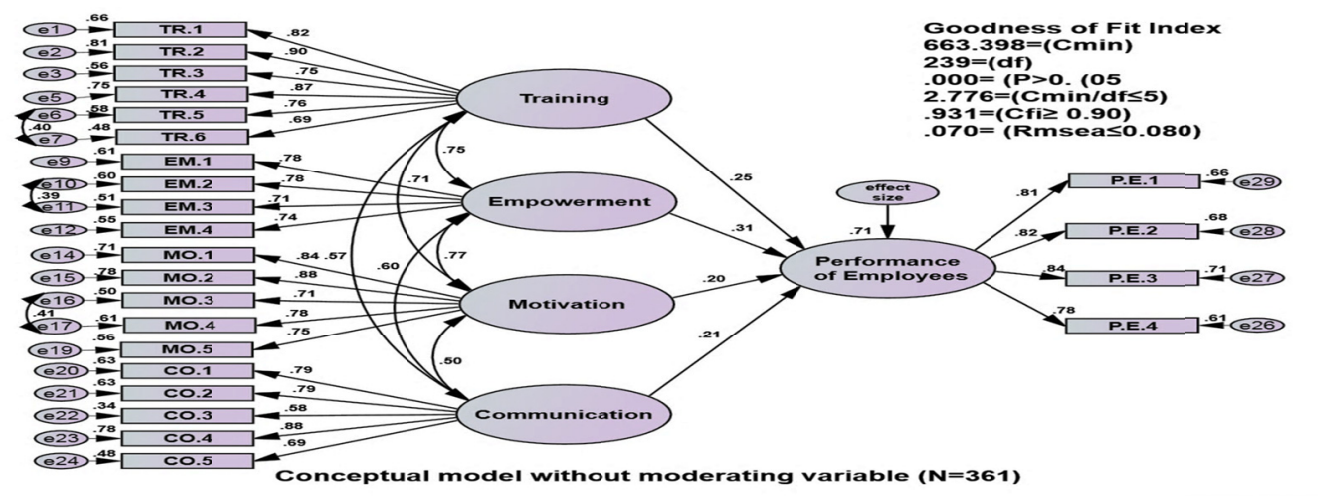

Figure 3. (Structural model N=361).

In addition, the reliability was greater than $0.7(\geq 0.7)$, it ranged from 0.951 to 0.954 . , the AVE reading were for factors between 0.57 to 0.67 where the value was greater than $0.5(\geq 0.5)$. Consequently, all results fulfilled the AVE, and the reliability discriminant validity of the model. In general, the measurement model of the Conceptual model without moderating variable was fit and fulfilled the construct as depicted in Table (3).

Table 3. Construct validity and Reliability of the Conceptual model without moderating variable

\begin{tabular}{ccccccccc}
\hline Items & Variables & Reliability & Estimate & S. E. & C. R. & P & Loading & AVE \\
\hline TR.1 & Training & 0.951 & 0.9661 & 0.0463 & 20.8591 & $* * *$ & 0.82 & 0.64 \\
TR.2 & Training & 0.951 & 1.0000 & - & - & - & 0.90 & - \\
TR.3 & Training & 0.951 & 0.8464 & 0.0472 & 17.9216 & $* * *$ & 0.75 & - \\
TR.4 & Training & 0.951 & 0.9420 & 0.0399 & 23.5825 & $* * *$ & 0.87 & - \\
TR.5 & Training & 0.951 & 0.8347 & 0.0451 & 18.5060 & $* * *$ & 0.76 & - \\
TR.6 & Training & 0.952 & 0.7701 & 0.0488 & 15.7664 & $* * *$ & 0.69 & - \\
EM.1 & Empowerment & 0.951 & 1.0192 & 0.0692 & 14.7383 & $* * *$ & 0.78 & 0.57 \\
EM.2 & Empowerment & 0.952 & 1.0000 & - & - & - & 0.78 & - \\
\hline
\end{tabular}




\begin{tabular}{llllllllcc}
\hline EM.3 & Empowerment & 0.952 & 0.9319 & 0.0538 & 17.3343 & $* * *$ & 0.71 & - \\
EM.4 & Empowerment & 0.952 & 0.9714 & 0.0692 & 14.0390 & $* * *$ & 0.74 & - \\
MO.1 & Motivation & 0.951 & 0.9376 & 0.0456 & 20.5580 & $* * *$ & 0.84 & 0.63 \\
MO.2 & Motivation & 0.951 & 1.0000 & - & - & - & 0.88 & - \\
MO.3 & Motivation & 0.952 & 0.7946 & 0.0512 & 15.5230 & $* * *$ & 0.71 & - \\
MO.4 & Motivation & 0.952 & 0.9131 & 0.0504 & 18.1270 & $* * *$ & 0.78 & - \\
MO.5 & Motivation & 0.951 & 0.8417 & 0.0492 & 17.1010 & $* * *$ & 0.75 & - \\
CO.1 & Communication & 0.953 & 0.8968 & 0.0498 & 18.0072 & $* * *$ & 0.79 & 0.57 \\
CO.2 & Communication & 0.953 & 0.8529 & 0.0474 & 18.0031 & $* * *$ & 0.79 & - \\
CO.3 & Communication & 0.954 & 0.6791 & 0.0579 & 11.7387 & $* * *$ & 0.58 & - \\
CO.4 & Communication & 0.952 & 1.0000 & - & - & - & 0.88 & - \\
CO.5 & Communication & 0.952 & 0.7703 & 0.0518 & 14.8811 & $* * *$ & 0.69 & - \\
PE.1 & Performance & 0.951 & 0.9174 & 0.0559 & 16.4130 & $* * *$ & 0.78 & 0.67 \\
PE.2 & Performance & 0.951 & 0.9793 & 0.0536 & 18.2629 & $* * *$ & 0.84 & - \\
PE.3 & Performance & 0.951 & 0.9969 & 0.0564 & 17.6638 & $* * *$ & 0.82 & - \\
PE.4 & Performance & 0.951 & 1.0000 & - & - & - & 0.81 & - \\
\hline
\end{tabular}

S.E. Standard Error, C.R.: Critical Ratio, P: Probability, SMC: Squared Multiple Correlations. $\quad$ AVE: Average Variance Extracted

11.4 Testing the Efficiency of the Conceptual Model between the Two Groups (Supporter of the Senior Management's Support, Not Supporter of the Senior Management's Support)

Table (4) reveals that the indicators of the Conceptual model for the first group which is the not supporter of the senior management's support and it did not correspond the specified criteria. And the value of the (CFI) was (0. 892) which was less than the value of the test (0.90) and this assures that the group which does not support the senior management's support did not correspond with the model. And the value of (RMSEA) was (0. 892) and big than the standard test (0.080). In the same table, it is clear that the indicators of the Conceptual model for the second group which supports the senior management's support and it correspond the specified criteria. And the value of (CFI) was (0.927) which was higher than the value of the test $(0.90)$. The value of the Root Mean Square Error of Approximation (RMSEA) was (0.0730) and less than the standard test (0.080).

Table 4. The Values of the Indicators of the Correspondence the Conceptual model between the two Groups (supporter of the senior management's support, not supporter of the senior management's support)

\begin{tabular}{ccccc}
\hline \multirow{2}{*}{$\begin{array}{c}\text { Parity } \\
\text { Indicators }\end{array}$} & $\begin{array}{c}\text { Pro-support group } \\
\text { model } 4\end{array}$ & $\begin{array}{c}\text { Non-pro-support } \\
\text { group model } 5\end{array}$ & $\begin{array}{c}\text { Standard Model } \\
\text { Differences in the } \\
\text { indicators between } \\
\text { the two models }\end{array}$ & $\begin{array}{c}\text { Function value on the } \\
\text { existence of differences in } \\
\text { the moderating variable }\end{array}$ \\
\cline { 2 - 4 } the value of the index & the value of the index & & 126.527 & more than Chi-square \\
probabilities
\end{tabular}

Based on the data in Table (4), there are differences between the two models in the (CFI) which was (0.035) and it was larger of the specified standard (0.01). As well as the differences between the two models in (RMSEA) index was (0.016) which exceeded the benchmark (0.015) (Barbara, 2010). This confirms the existence of differences in the model of the Conceptual model between the first and second group. Also, this indicates that the model of the Conceptual model was very appropriate for the second group (the supporter of the senior management's support). But the result of the first group (not a supporter of the senior management's support) was inappropriate for the model. This assures that the relationship between the independent factors model (Training, Empowerment, Motivation and Communication) and the dependent factor (Performance of Employees) are better in the supporter group than the non-supporter group, and we can test the hypotheses of the study. 


\section{Testing the Main Hypotheses of the Moderating Variable (Senior Management's Support)}

12.1 (H1): Supportive Senior Management reinforces the relationship between training and Employees' Performance in the al-Zawiya university of Libya.

By looking at Table (5), Figure (4) and Figure (5) it is clear to us the existence of differences in the relationship between the Training and the Employees' Performance between the two groups. It is clear that the supporter group (second) better than the non-supporter group (first) in terms of Estimate values (0.2505 -0.3338) and (SE) $(0.067-0.438)$ and $(C R)$ value $(3.704-0.761)$ and the level of significance $(0.000-0.4462)$. This confirms the strength and enhances the relationship between the two variables in the presence of senior management's support.

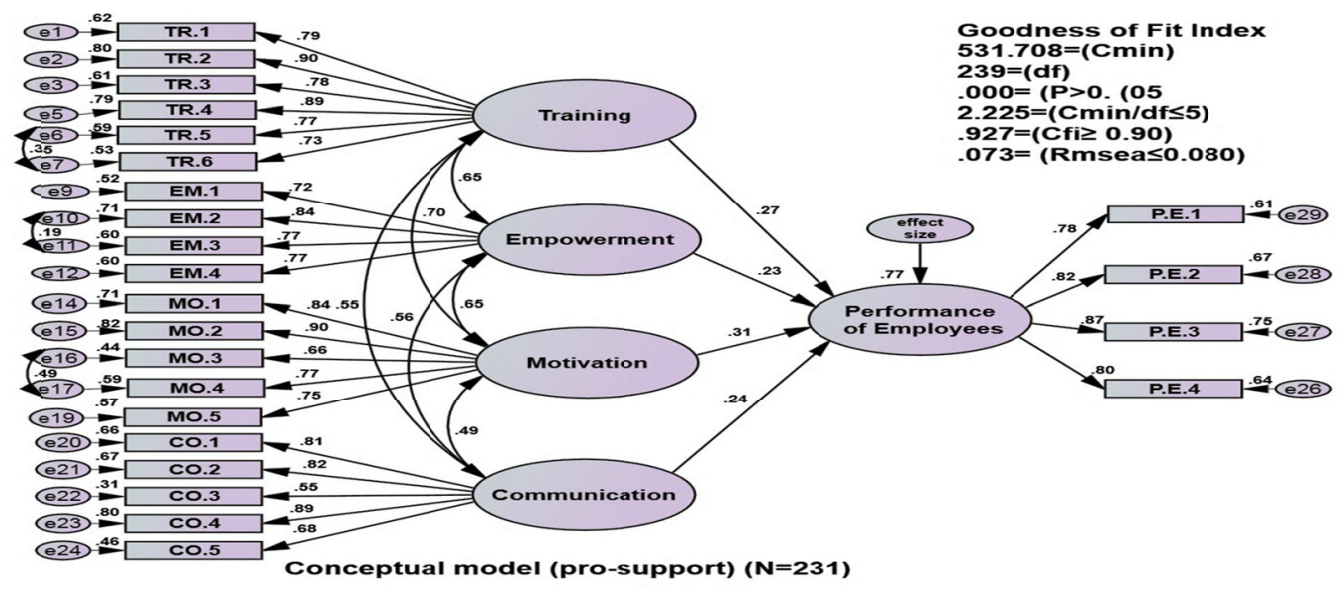

Figure 4. structural model (Pro-support group $\mathrm{N}=231$ )

12.2 (H2): Supportive senior management reinforces the relationship between empowerment and Employees' Performance in the al-Zawiya university of Libya.

The results presented in Table (5), Figure (4) and Figure (5) it is clear to us the existence of differences in the relationship between Empowerment and Employees' Performance between the two groups. It is clear that the supporter group (second) better than the non-supporter group (second) in terms of Estimate values $(0.2223$ -1.9976) and (SE) (0.069 - 1.276) and (CR) value (3.220- 1.564) and the level of significance (0.0013- 0.1176). This confirms the strength and enhances the relationship between the Empowerment and Employees' Performance in the presence of senior management's support.

12.3 (H3): Supportive senior management reinforces the relationship between motivation and Employees' Performance in the al-Zawiya university of Libya.

Results are shown in Table (5), Figure (4) and Figure (5), the relationship between work motivation and employees' performance differs in the two groups of participants. In other words, the Estimate values $(0.2805$ $-0.6251)$ and (SE) (0.066 - 0.668) and (CR) value (4.248-0.934) and the level of significance (0.000- 0.3498) are better in the supporter group (second) better than the non-supporter group (second) in terms of. Such result is indicative of the strong relationship between motivation and Employees' Performance in the presence of senior management's support.

12.4 (H4): Supportive senior management reinforces the relationship between communication and Employees' Performance in the al-Zawiya university of Libya.

The Fourth hypothesis supports the evidence of the positive effect of senior management's support on the relationship between the communication and Employees' Performance in the Al-Zawiya University of Libya. In other words, there is a difference between the supporter group and the non-supporter group, and the correlation values of the relationship in the second group are higher than the values of the first group. The results shown in Table (5), Figure (4) and Figure (5) indicate that the supporter group (second) is better than the non-supporter group (first) in terms of Estimate values (0.2095-0.1499) and (SE) (0.051- 0.131) and (CR) value (4.059-1.142) and the level of significance $(0.000-0.2533)$. Thus, the results suggest that support of senior management contributes to the relationship between communication and performance of employees. 


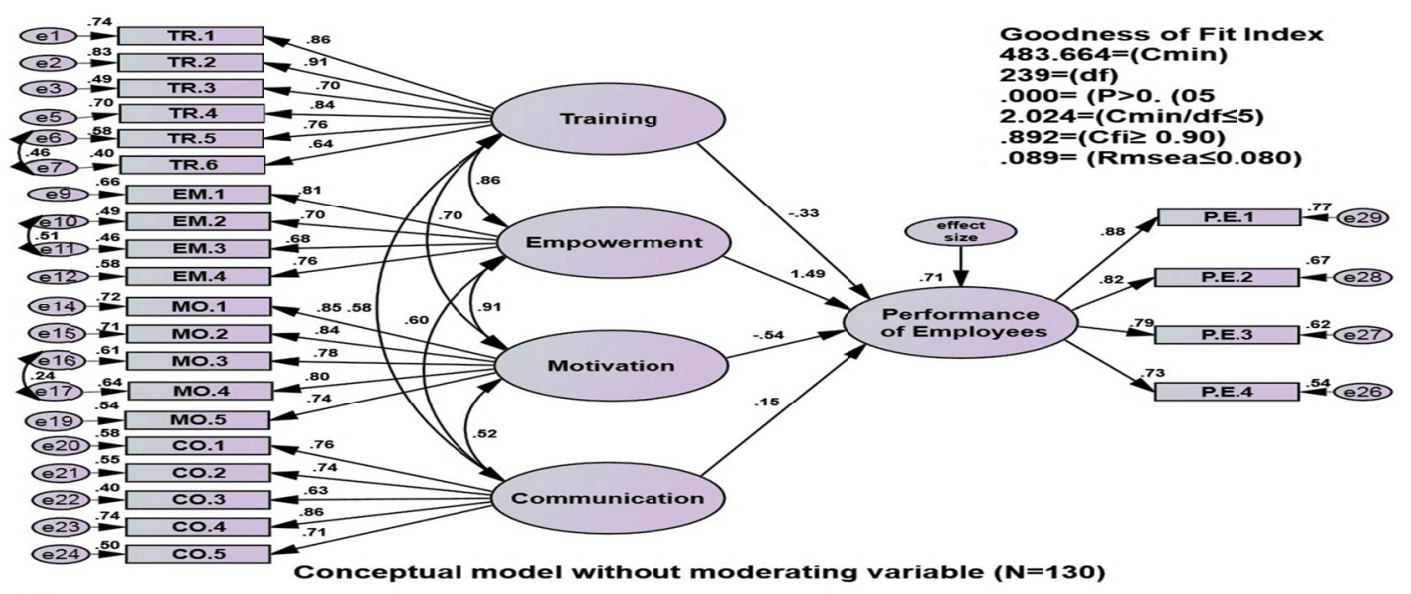

Figure 5. Structural model (Non-Pro-support group N=130)

Table 5. Standard and transactions for conceptual model between the two groups

\begin{tabular}{|c|c|c|c|c|c|c|c|}
\hline $\begin{array}{c}\text { Independent } \\
\text { variable }\end{array}$ & $\begin{array}{c}\text { Dependent } \\
\text { variable }\end{array}$ & $\overline{\mathbf{E}}$ & S.E & C.R & $\mathbf{P}$ & Effect & $\begin{array}{c}\text { Hypothesis } \\
\text { Support }\end{array}$ \\
\hline \multicolumn{8}{|c|}{ Training $\quad---\rightarrow$ Performance } \\
\hline \multicolumn{2}{|c|}{ supporter of the senior management's support } & 0.2505 & 0.067 & 3.704 & $* * *$ & 0.27 & Asserted \\
\hline \multicolumn{2}{|c|}{ Not supporter of the senior management's support } & -0.3338 & 0.438 & -0.761 & 0.4462 & -0.33 & \\
\hline \multicolumn{8}{|c|}{ Empowerment $-\ldots$ Performance } \\
\hline \multicolumn{2}{|c|}{ supporter of the senior management's support } & 0.2223 & 0.069 & 3.220 & 0.0013 & 0.23 & Asserted \\
\hline \multicolumn{2}{|c|}{ Not supporter of the senior management's support } & 1.9976 & 1.276 & 1.564 & 0.1176 & 1.49 & \\
\hline \multicolumn{8}{|c|}{ Motivation $\quad---\rightarrow$ Performance } \\
\hline \multicolumn{2}{|c|}{ supporter of the senior management's support } & 0.2805 & 0.066 & 4.248 & $* * *$ & 0.31 & Asserted \\
\hline \multicolumn{2}{|c|}{ Not supporter of the senior management's support } & -0.6251 & 0.668 & -0.934 & 0.3498 & -0.54 & \\
\hline \multicolumn{8}{|c|}{ Communication $-{ }_{-} \rightarrow$ Performance } \\
\hline \multicolumn{2}{|c|}{ supporter of the senior management's support } & 0.2095 & 0.051 & 4.059 & $* * *$ & 0.24 & Asserted \\
\hline \multicolumn{2}{|c|}{ not supporter of the senior management's support } & 0.1499 & 0.131 & 1.142 & 0.2533 & 0.15 & \\
\hline
\end{tabular}

\section{Conclusion}

The present study tested the role of the senior management as a supporter for the performance of employees; this study was conducted on the Employees in the Al-Zawiya University of Libya. Factor analysis assertive was used for the senior management variable and the results showed the appropriateness of the model according to the indicators of the structural equation modeling (SEM). The impact of the influential variable (the senior management) was measured by using the analysis of samples, or what is known as a multiple-groups approach, where the subjects were divided into two groups, depending on the mean of the total paragraphs. The group which is less than the mean is not a supporter (the first group). And the group which is higher than the mean is the supporter of the Senior Management's support (the second group). The study found that the Conceptual model in the presence of the support of the senior management is appropriate for the second group and inappropriate in light of the lack of support for the senior management for the first group. The findings of the study confirmed the important role of the Senior Management's support as factor which affects positively the Employees' Performance in the Al-Zawiya University of Libya and this results also agreed with previous studies, such as (Van de Ven, 1993; Storey, 2000; Aragón-Correa et al., 2007; Jung et al., 2003; Ryan \& Tipu, 2013; Abrell et al., 2011; Taylor et al., 2009; Cho \& Hambrick, 2006; Kor, 2003; Stam \& Elfring, 2008; Smith \& Tushman, 2005; Wu et al., 2005; Oke et al., 2009; Chahine \& Goergen, 2013; Agbim et al., 2013).Finally, the contribution of the present study is in testing the impact of the role of the Senior Management's support in supporting the Employees' Performance in the Al-Zawiya University of Libya.

\section{The Study Contribution, Implications, and Limitations}

The results of the present study show that while, the support of senior management positively affects employees' job performance, training, empowerment, motivation, and communication assist in modifying top employees' behaviors to become more efficient in performing their work (Ryan, and Tipu, 2013; Abrell et al., 2011; Taylor et 
al., 2009). Hence, the availability of support of top management enables organizations to adapt to environmental factors, constraints, and take an advantage of the available opportunities. As an important key element for the long-term existence of organizations, innovation requires careful selection of directors who have characteristics of good leadership. Moreover, managers should be well trained on what and how to how to adopt effective methods of management and leadership while taking into account managers' salaries. This is because as highlighted in previous research, rewarding top management is important in fostering innovation and supporting such innovational efforts in managing their companies (Makri et al., 2006; Makri, and Scandura, 2010). Based on the results of the study, top management is an important key in innovation generation or creation since it offers an appropriate environment and facilitates accurate decisions that enhance the generation and application of knowledge. The needs for innovation assist individuals in the organization to make efforts in better learning of new knowledge through continuous engagement in teamwork. The present study provided evidence of the important role of the synergy between top management and employees in making the organization more adaptable. Senior management's support has a significant role in easing the processes of communication and coordination processes between different functions in organizations, thus achieving the benefits at the organizational and individual levels. It also results in changing individuals' (administrators and employees) lives for better. However, training employees for the purpose of improving their knowledge, skills, and experience becomes necessary. In addition, top management should support productivity by providing a new working environment and encouraging work atmosphere for employees. Organizational structures which are less formal and less cartelized provide employees with the opportunity to be innovative and creative in their work (Chen, 2007). Senior Management's Support also assists both organizations and individuals to pursue their survival and be updated with the latest knowledge and development around them. The study contributes to earlier research through the tool for measuring the impact of top management support through the relationship between senior management and employees on innovation in developing countries. This will hopefully be valuable for future research in this research area. Another contribution of the present study is the evidence that supports the role of the supportive senior management in reinforcing the relationship among these factors: training, empowerment, motivation, and communication and performance of employees. These results can be also useful and significant for managers of the Libyan organizations. For instance, this study is expected to make organizations abler to offer the public innovative products or services, or enhances employees' performance, thus promoting their innovative thinking and creating a learning base for innovative ideas. However, the limitation of the current study is the study sample since it was carried out only in one university in a Libyan city.

\section{References}

Abrell, C, Rowold, J., Weibler, J., \& Moenninghoff, M. (2011). Evaluation of a long-term transformational leadership development program. Zeitschrift Fur Personalforschung, 25(3), 205-224. https://doi.org/10.1177/239700221102500307

Agbim, K C. (2013). The relative contribution of management skills to entrepreneurial success: A survey of small and medium enterprises (SMEs) in the trade sector. International Organization of Scientific Research Journal of Business and management, 7(1), 08- 16.

Al-Refaie, A., Ghnaimat O., \& KO, J. H. (2011). The effects of quality management practices on customer satisfaction and innovation: a perspective from Jordan. International Journal of Productivity and Quality Management, 8(4), 398-415. https://doi.org/10.1504/IJPQM.2011.043007

Aragón-Correa, J. A, García-Morales, V. J., \& Cordón-Pozo, E. (2007). Leadership and organizational learning's role in innovation and performance: lessons from Spain. Industrial Marketing Management, 36(3), 349-359. https://doi.org/10.1016/j.indmarman.2005.09.006

Arinanye, R. T. (2015). Organizational Factors Affecting Employee Performance at the College of Ccoputing and Information Sciences (CoCIS), Makerere University, Kampala - Uganda.

Berman, E. M., Bowman, J. S., West, J. P., \& Wart, M. R. V. (2010). Motivation: Possible, Probable or Impossible? Human Resource Management in Public Service: Paradoxes, Processes and Problems (pp. 180). California: SAGE Publications, Inc.

Boehm, A., \& Staples, L. (2002). The functions of the social worker in empowering the voices of consumers and professionals. Social Work, 47, 337-480. https://doi.org/10.1093/sw/47.4.449

Bowen, F. E., Rostami, M., \& Steel, P. (2010). Timing is everything: A meta-analysis of the relationships between organizational performance and innovation. Journal of Business Research, 63(11), 1179-1185. https://doi.org/10.1016/j.jbusres.2009.10.014 
Brown, E. (2008). Dimensions of Transformational leadership and relationship with employee performance in hotel front desk staff. ProQuest Information and Learning Company. IOWA.

Browne, M. W., \& Cudeck, R. (1993). Alternative ways of assessing model fit. Sage.Focus Editions, 154, 136.

Byrne, B. M. (2010), Structural Equation Modeling with AMOS: Basic Concepts, Applications, and Programming (2nd ed.).

Camden, C., \& Witt, J. (1983). Manager communicative style and productivity: A study of female and male managers. International Journal of Women's Studies, 6, 258-269.

Chahine, S., \& Goergen M. (2013). The effects of management-board ties on IPO performance, Journal of Corporate Finance, 21, 153-179. https://doi.org/10.1016/j.jcorpfin.2013.02.001

Chen, C. J. (2007). Information technology, organizational structure, and new product development-the mediating effect of cross-functional team interaction. IEEE Transaction on Engineering Management, 54(4), 687-698. https://doi.org/10.1109/TEM.2007.906831

Chng, H., et al. (2014). Factors Affect Employee Performance in Hotel Industry, University Tunku Abdul Rahman, Faculty of Business and Finance Department of Business.

Cho T. S., \& Hambrick, D. C. (2006). Attention patterns as mediators between top management team Characteristics and strategic change: The case of airline deregulation. Organization Science, 17(4), 453-469. https://doi.org/10.1287/orsc.1060.0192

DeCenzo, D. A., \& Robbins, S. P. (1996). Human resources management. New York: John Wiley \& Sons, Inc.

Denti, L. (2012). Leadership and innovation in organizations: a systematic review of factors that mediate or moderate the relationship more. International Journal of Innovation Management, 16(3),

Devaraj, S., Fan, M., \& Kohli, R. (2002), Antecedents of B2C Channel Satisfaction and Preference: Validating e-Commerce Metrics. Information Systems Research, 13(3), 316-333. https://doi.org/10.1287/isre.13.3.316.77

Ekerman, G. (2006). Job Enrichment and Staff Motivation. Human Resource Management (pp. 183-191). Cape Town: Maskew Miller Longman (Pvt) Ltd.

Elenkov, D. S., Judge, W., \& Wright, P. (2005). Strategic leadership and executive innovation influence: An international multi-cluster comparative study. Strategic Management Journal, 26(7), 665-682. https://doi.org/10.1002/smj.469

Esmael, M., \& Tabouli1, A. (2016). The Impact of Human Resources Management on Employee Performance: organizational commitment mediator variable. Asian Social Science, 12(9).

Finkelstein, S., \& Hambrick D.C. (1996). Strategic leadership: top executives and their effects on organizations. Australian Journal of management, 22(2), 221- 224.

Fisher, D. M. (2012). Facet personality and surface-level diversity as team mental model antecedents: Implications for implicit coordination. Journal of Applied Psychology, 97(4), 825-841. https://doi.org/10.1037/a0027851

Fornell, C., \& Larcker, D. F. (1981). Evaluating structural equation models with unobservable variables and measurement error. Journal of Marketing Research, 18(1), 39-50. https://doi.org/10.2307/3151312

Gurland, S. T., \& Lam, C. F. (2008). Self-determined work motivation predicts job outcomes, but what predicts self-determined work motivation? Journal of the world (pp. 1161-1162). Thousand Oaks, CA: SAGE Publications, Inc.

Hair, J., Black, B. Babin, B., Anderson, R., \& Tatham, R. (2006). Multivariate Data Analysis (6th ed.). Upper Saddle River, NJ: Prentice-Hall.

Hair, J., Black, B. Babin, B., Anderson, R., \& Tatham, R. (2006). Multivariate Data Analysis 6th edition. Upper Saddle River, NJ: Prentice-Hall 154, 136.

Hair, J., Black, W, Babin, B., \& Anderson, R. (2010). Multivariate data analysis: A global perspective (7th ed.). Pearson Education, Inc. Saddle River, New Jersey.

Hersen, M. (2004). Comprehensive Handbook of Psychological Assesment; Industrial and Organizational Assessment. John Wiley \& Sons Inc. New Jersey.

Huang, Y. H., Li, E. Y., \& Chen, J. S. (2009). Information synergy as the catalyst between information 
technology capability and innovativeness: empirical evidence from the financial service sector. Information Research, 14(1), 380-394.

Ifinedo, P. M. (2007). Interactions between organizational size, culture, and structure and some it factors in the context of ERP success assessment: an exploratory investigation. Journal of Computer Information Systems, $47,28-44$.

Ireland, R. D., \& Hitt, M. A. (1999). Achieving and maintaining strategic competitiveness in the $21^{\text {st }}$ century: the role of strategic leadership. Academy of Management Executive, 13(1), 43-57.

Johnson, B., \& Christensen, L. (2012). Educational research. Quantitative, qualitative, and mixed approaches (4th ed.). California: Sage Publication Inc.

Jung, D. I., Chow, C., \& Wu, A. (2003). The role of transformational leadership in enhancing organizational innovation: Hypotheses and some preliminary findings. The Leadership Quarterly, 14, 525-544. https://doi.org/10.1016/S1048-9843(03)00050-X

Kamery, R. H. (2004). Motivational Techniques for Positive Reinforcement: A Review. Allied Academies International Conference, 8(2), 91-96.

Karlan, D., \& Valdivia, M. (2011). Teaching entrepreneurship: Impact of business training on microfinance clients and institutions. Review of Economics and Statistics, 93(2), 510-27. https://doi.org/10.1162/REST_a_00074

Kim, D. Y., Kumar, V., \& Kumar, U. (2012). The relationship between quality management practices and innovation. Journal of Operations Management, 30, 295-315. https://doi.org/10.1016/j.jom.2012.02.003

Kirkpatrick, D. L. (2006). Improving Employee Performance through Appraisal and Coaching (2nd ed.). Amacon Publishers, New York.

Kor, Y. Y. (2003). Experience-based top management team competence and sustained growth. Organization Science, 14, 707-719. https://doi.org/10.1287/orsc.14.6.707.24867

Linz, S. J., Good, L. K., \& Huddleston, P. (2006). Worker morale in Russia: an exploratory study. Journal of Managerial Psychology, 21(5), 415-437. https://doi.org/10.1108/02683940610673951

MacCallum, R. C., Browne, M. W., \& Sugawara, H. M. (1996). Power Analysis and Determination of Sample Size for Covariance Structure Modeling. Psychological Methods, 1(2), 130-49. https://doi.org/10.1037/1082-989X.1.2.130

Makri, M., \& Scandura, T. A. (2010). Exploring the effects of creative CEO leadership on innovation in high technology firms. The Leadership Quarterly, 21, 75-88. https://doi.org/10.1016/j.leaqua.2009.10.006

Manna, A. Q. (2012). Evaluation of the role of top management in achieving synergy between organizational structure and information technology in communications and banking sectors. Doctoral theses, Amman Arab University, Jordan.

Marsh, H. W., \& Hocevar, D. (1985). Application of confirmatory factor analysis to the study of self-concept: First-and higher order factor models and their invariance across groups. Psychological bulletin, 97(3), 562-582. http://dx.doi.org/10.1037/0033-2909.97.3.562

McDonald, R. P., \& Marsh, H. W. (1990). Choosing a multivariate model: No centrality and goodness of fit. Psychological Bulletin, 107(2), 247-255. https://doi.org/10.1037/0033-2909.107.2.247

Mudor, H., \& Tooksoon, P. (2011). Conceptual Framework on the Relationship between Human Resource Management Practices, Job Satisfaction, and Turnover. Journal of Economics \& Behavioral Studies, 2(2), 41-49.

Neelam, I. et al. (2014). The Impact of Training and Development on Employees Performance and Productivity: A case study of United Bank Limited Peshawar City, KPK. Pakistan: International Journal of Academic Research in Business and Social Sciences, 4(4).

Njambi, C. (2014). Factors Influencing Employee Motivation and ITS Impact on Employee Performance: A case of Amref Health Africa in Kenya: A Research Project Report Submitted to Chandaria School of Business in Partial Fulfillment of the Requirement for the Degree of Masters in Business Administration (MBA).

Oke, A., Munshi, N., \& Walumbwa, F. O. (2009). The influence of leadership on innovation processes and activities. Organizational Dynamics, 38(1), 64-72. https://doi.org/10.1016/j.orgdyn.2008.10.005

Ololube, N. P. (2006). Teachers job satisfaction and motivation for school effectiveness. An assessment. 
Retrieved from http://www.usca.edu/essays/vol182006/ololubepdf

Papa. M. J., \& Tracy, K. (1987, May). Communicative indices of employee performance with new technology. Paper presented at the annual meeting of the International Communication Association, Montreal, Canada.

Perry-Smith, J. E. (2006). Social yet creative: The role of social relationships in facilitating individual creativity. Academy of Management Journal, 49(1), 85-101. https://doi.org/10.5465/AMJ.2006.20785503

Ran, B. (2009). Motivation. In C. Wankel (Ed.), Encyclopedia of business in today's. Research in Personality, 42(4), 1109-1115. https://doi.org/10.4135/9781412964289.n668

Robinson, D. (1995). The Impact of Cognitive Skills Training on Post Release Recidivism among Canadian Federal Offenders. Research Report No. R-41 Correctional Service Canada.

Ryan, A. M., \& Sackett, P. R. (1987). A survey of individual assessment practices by I / O psychologists. Personnel Psychology, 40, 387-455. https://doi.org/10.1111/j.1744-6570.1987.tb00610.x

Ryan, J. C, Syed, A. A., \& Tipu, S. A. (2013). Leadership effects on innovation propensity: A two-factor full range leadership model. Journal of Business Research, 66(10), 2116-2129. https://doi.org/10.1016/j.jbusres.2013.02.038

Schulze, S., \& Steyn, T. (2003). Educator's motivation: differences related to gender, age, and experience. Acta Academia, 35(3), 138-160.

Schumacker, R. E., \& Lomax, R. G. (2010). A beginner's guide to structural equation modeling (3rd ed.). New York: Routledge.

Sekaran, U., \& Bougie R. (2010). Research methods for business: A skill building approach (5th ed.). Wiley and Sons.

Sharma, S., \& Rai, A. (2003). An assessment of the relationship between ISD leadership characteristics and IS innovation adoption in organizations. Information and Management, 40(5), 391-401. https://doi.org/10.1016/S0378-7206(02)00049-6

Smith, W. K., \& Tushman, M. L. (2005). Managing strategic contradictions: A top management model for managing innovation streams. Organization Science, 16(5), 522-536. https://doi.org/10.1287/orsc.1050.0134

Snyder, R. A., \& Morris, J. H. (1984). Organizational communication and performance. Journal of Applied Psychology, 69, 461-465. https://doi.org/10.1037/0021-9010.69.3.461

Stam, W., \& Elfring, T. (2008). Entrepreneurial orientation and new venture performance: The moderating role of intra- and extra industry social capital. Academy of Management Journal, 51(1), 97-111. https://doi.org/10.5465/AMJ.2008.30744031

Storey, J. (2000). The management of innovation problem. International Journal of Innovation Management, 4(3), 347-369. https://doi.org/10.1142/S1363919600000196

Tanveer, Y., \& Zeeshan, M. (2011). The way Human Resource Management (HRM) Practices Effect Employees Performance: A Case of Textile Sector. International Journal of Economics and Management Sciences, 1(4), 112-117.

Tavitiyaman, P. (1996). The effect of Management Commitment to Service Quality on Employees' Job Satisfaction and Prosaically Service Behaviors: Thammasat University, Bangkok, Thailand, Faculty of the Graduate College of the Oklahoma State University.

Taylor, P. J., Taylor, H., \& Russ-Eft, D. F. (2009). Transfer of management training from alternative technological dynamism. Academy of Management Journal, 48(5), 859-873.

Tulloch, S. (Ed.) (1993). The Reader's Digest Oxford Wordfinder. Oxford: Clarendon.

Turban, E., \& Volonino, L. (2010). Information technology for management transforming organizations in the digital economy (7th ed.). Hoboken, NJ: Jon Wiley and Son, Inc.

Van de ven, A. H. (1993). Managing the process of organizational innovation. In G. P. Huber, \& W. H. Glick (Eds.), Organizational change and redesign: Ideas and insights for improving performance (pp. 269-294). New York' Oxford University Press.

Wallach, V., \& Mueller, C. (2006). Job characteristics and organizational predictors of psychological empowerment among paraprofessionals with human service organizations: An exploratory study. 
Administration in Social Work, 30(1), 95-115. https://doi.org/10.1300/J147v30n01_06

Wang, Z., \& Wang, N. (2012). Knowledge sharing, innovation and firm performance. Expert Systems with Applications, 39, 8899-8908. https://doi.org/10.1016/j.eswa.2012.02.017

West, M. A., Borrill, C., Dawsonm J., Brodbeck, F., Shapiro, D. A., \& Haward, B. (2003). Leadership clarity and team innovation in health care. Leadership Quarterly, 14, 393-410. https://doi.org/10.1016/S1048-9843(03)00044-4

Wiengarten, F., Humphreys, P., Cao, G., \& McHugh, M. (2013). Exploring the important role of organizational factors in IT Business value: taking a contingency perspective on the resource-based view. International Journal of Management Reviews, 15, 30-46. https://doi.org/10.1111/j.1468-2370.2012.00332.x

Wu, S, Levitas, E., \& Priem, R. L. (2005). CEO tenure and company invention under differing levels of Technological dynamism. Academy of Management Journal, 48(5), 859-873. https://doi.org/10.5465/AMJ.2005.18803927

\section{Appendix A}

\begin{tabular}{|c|c|c|}
\hline Variables & Items & Paragraphs \\
\hline \multirow{6}{*}{$\begin{array}{l}\text { Training and } \\
\text { Development }\end{array}$} & TR.1 & Training and development is essential for college's employees. \\
\hline & TR.2 & Competency level of employees increases due to training and development. \\
\hline & TR.3 & Training and development reduce the stress of the employees. \\
\hline & TR.4 & Performance and productivity greatly depend on Training and development. \\
\hline & TR.5 & $\begin{array}{l}\text { Training and development enhance the performance and productivity of the employees } \\
\text { as well as of the organization. }\end{array}$ \\
\hline & TR.6 & $\begin{array}{l}\text { Training and development reduce consumption of time and cost and increase } \\
\text { performance and productivity. }\end{array}$ \\
\hline \multirow{4}{*}{ Empowerment } & EM.1 & $\begin{array}{l}\text { My supervisor gives more freedom and authority which can make my job easier, faster } \\
\text { and effective. }\end{array}$ \\
\hline & EM.2 & $\begin{array}{l}\text { The great autonomy and ability to make a decision can make my job more convenient } \\
\text { especially for clients. }\end{array}$ \\
\hline & EM.3 & The power sharing among employee will help to reduce work related stress. \\
\hline & EM.4 & $\begin{array}{l}\text { Mutual trust among employees will enhance the power and authority of the decision } \\
\text { making. }\end{array}$ \\
\hline \multirow{5}{*}{ Motivation } & MO.1 & $\begin{array}{l}\text { I am more motivated to do my job when I feel I am recognized and appreciated for my } \\
\text { contribution to the organization. }\end{array}$ \\
\hline & MO.2 & The degree of skill variety required to perform my job has an impact on my motivation. \\
\hline & MO.3 & How meaningful I believe my work has an influence on my motivation level. \\
\hline & MO.4 & $\begin{array}{l}\text { The degree of trust exhibited at my work place is a determinant of my level of } \\
\text { motivation at work. }\end{array}$ \\
\hline & MO.5 & $\begin{array}{l}\text { I am more motivated to perform my job when I feel there is fairness of treatment at the } \\
\text { workplace. }\end{array}$ \\
\hline \multirow{5}{*}{ Communication } & CO.1 & I get timely communication about the decisions of the different organs in this College. \\
\hline & CO.2 & There is open communication in this College. \\
\hline & $\mathrm{CO} .3$ & This College has good cross unit communication. \\
\hline & $\mathrm{CO} .4$ & All-College meetings are always well organized. \\
\hline & CO.5 & The College's communication makes me identify with it or feel a vital part of it. \\
\hline \multirow{4}{*}{$\begin{array}{l}\text { Employees' } \\
\text { Performance }\end{array}$} & PE.1 & I feel dedication, seriousness, and ability to take responsibility. \\
\hline & PE.2 & I do my work according to specific policies and procedures. \\
\hline & PE.3 & $\begin{array}{l}\text { I enjoy professional skill or professionalism and technical knowledge required to carry } \\
\text { out the work efficiently. }\end{array}$ \\
\hline & PE.4 & I feel satisfied with the work I do in the university. \\
\hline \multirow{2}{*}{$\begin{array}{l}\text { Senior Management's } \\
\text { Support }\end{array}$} & M1 & $\begin{array}{l}\text { My immediate supervisor often asks for opinions / suggestions on important issues } \\
\text { relating to this College. }\end{array}$ \\
\hline & M2 & $\begin{array}{l}\text { My immediate supervisor often gives me information/suggestions or feedback on } \\
\text { important issues relating to this College. }\end{array}$ \\
\hline
\end{tabular}


M3 The College's where I work for favors autonomy in doing tasks and making decisions.

M4 In the College's where I work, training is evaluated by participants.

M5 The College's I work for stimulates learning and application of knowledge.

M6 In the College's where I work, training needs are identified periodically.

M7 The college tries to make my job as interesting as possible.

M8 My College strongly considers my goals and values.

M9 In the College's where I work offers me a salary that is compatible with my skills, training, and education.

M10

In the College's where I work remunerates me according to the remuneration offered at either the public or private marketplace levels.

M11

In the College's where I work, there is an environment of understanding and confidence between managers and employees.

\section{Copyrights}

Copyright for this article is retained by the author(s), with first publication rights granted to the journal.

This is an open-access article distributed under the terms and conditions of the Creative Commons Attribution license (http://creativecommons.org/licenses/by/4.0/). 